\title{
SCAB RESISTANT APPLE CULTIVARS FOR JUICE PRODUCTION
}

\author{
Monika MIESZCZAKOWSKA-FRĄC*, Witold PŁOCHARSKI, \\ Dorota KRUCZYŃSKA, Jarosław MARKOWSKI \\ National Institute of Horticultural Research \\ Konstytucji 3 Maja 1/3, 96-100 Skierniewice, Poland
}

Received: June 2020; Accepted: February 2021

\begin{abstract}
The purpose of this experiment was a selection of scab resistant apple cultivars suitable for juice production. Special attention was paid to cloudy juices. During three successive seasons, apple cultivars were processed into juices using laboratory method of juice extraction. Considering the possibility of both clear and cloudy juice production, apples were pressed with and without mash enzymation. The parameters investigated were: pressing yield, titratable acidity, soluble solids, juice density, and juices' sensory characteristics. Average values indicate that all the cultivars fulfilled the requirements of the Code of Practice of the European Fruit Juice Association concerning investigated chemical components, however, in single years, there were some deviations that should be taken into consideration offering single cultivar juices. Considering a low yield of juice without mash enzymation (below 70\%), cultivars 'Renora' and 'Retina' are not recommended for cloudy juice production. Sensory quality of juices, irrespectively if cloudy or clear, depended mostly on taste acceptability and in fact on soluble solids to acidity ratio. Juices with the ratio above 17 were usually scored higher concerning the taste than those with lower values. An example of exception was 'Free Redstar' which is highly astringent. Considering the efficiency of pressing and soluble solids content several investigated cultivars were highly suitable for concentrated apple juice production. Especially valuable may be considered 'Regine', 'Rebella', 'Sawa', and 'Topaz' and can be recommended for planting in industrial orchards, which became of special interest in recent years.
\end{abstract}

Key words: juices, clear, cloudy, yield, quality parameters

\section{INTRODUCTION}

Apples occupy one of the key positions in world fruit production. According to the United States Department of Agriculture (IndexMundi 2019), global commercial production of apples per year over the last ten years was 63,827 thousand tons; out of this production, in the European Union was 12,232 thousand tons. Major producers of apples are China, USA, and Poland. The average production of apples per year in Poland in the years 2010-2019, according to the Central Statistical Office (Statistics Poland), was 2,980 thousand tons; out of this, up to $56 \%$ were destined for processing mainly for concentrated juice production (Nosecka 2018). Apples intended for processing, and especially for concentrate production, are primarily those which do not fulfill specific marketing standards defined in the Commission Regulation (EU) No 543/2011 for fresh market supply. Fruit for juice production must fulfill the general requirements concerning quality, as defined in Council Directive 2001/112/EC and its amendment (Directive 2012/12/EU). In particular, the fruit must be sound and ripe, fresh, or preserved by chilling. 
However, the apple juice industry has more specific requirements concerning raw material quality. Therefore, over time evolved the idea of industrial orchards to produce the fruit of highly preferred quality. This idea has been of interest over several years (Fischer et al. 2001; Ozimek 2007) and it is still a subject of promotion. Ebert (2017) defined important principles of industrial orchard systems and specified several preconditions that must be considered. One of the most important prerequisites is the availability of disease-resistant, heavily cropping cultivars, highly suitable for processing. Scab resistant apples are of interest, as they are also suitable for establishing organic apple production, because of environmental protection, and need to limit residue level in fresh and processed fruit. The processing industry is interested in producing organic apple juice, for which there is a high demand in the market. Breeding of apple cultivars resistant to diseases has been carried out in many countries all over the world. There are about 100 scab resistant apple cultivars available commercially, but only a few are used by growers (Holb 2009). The reason is that the research concentrated on resistance, not on external and internal fruit quality, which according to that author, should be an equal priority.

The suitability of apples for processing may be based on different indexes: technological (e.g., suitability for a particular product), chemical (the content of soluble solids, acidity, pro-health components, etc.), sensory (balance of different components), economical (e.g., pressing yield). In the case of clear juices, which in general are processed into clear apple juice concentrate, the content of soluble solids and acidity strongly affects production profitability. Because of the requirements of the directive 2012/12/EU, that does not allow the addition of sugars and sweeteners to fruit juices, low variability, and the right proportion of soluble solids to acids in apples may be of high importance for direct juice production. Therefore, dessert apples may be highly suitable for apple juices not from concentrate (NFC) (Teleszko et al. 2016), however, their quality is highly dependent on apple cultivar and technology of cloudy juice production (Markowski et al. 2015; Teleszko et al. 2016).
Several scab resistant apple cultivars bred in Pillnitz, Germany, suitable for processing have been described in an article by Fischer et al. (2001). All the so-called "Re-cultivars" were judged positively considering the sensory parameters, however, allowing for internal quality factors 'Remo', 'Rene', 'Rewena', and 'Relinda' were judged as suitable for processing into apple juice, whereas others needed more testing. According to Fischer and Fischer (2008), in Germany, there is about 2,000 ha of commercial orchards that produce apples of scab resistant Re-cultivars ${ }^{\mathrm{TM}}$, mostly for processing. Establishment of industrial orchards with valuable scab resistant apple cultivars, taking also into consideration the suitability for processing, gives a chance for sustainable production of fruits. It also might ease a controversy between apple growers and processors concerning prices of processing apples, which highly fluctuate between the growing seasons (Markowski \& Płocharski 2018). It is worth mentioning that there are endeavors to regulate the situation by convincing fruit producers and processors to cooperate within the system of supply contracts (Regulation (EU) No 1308/2013). There is a possibility to select out of the available apple scab resistant cultivars material that would be useful for processing not only for concentrated juice production but also for direct juice (NFC), which is becoming a commodity of interest for processors and consumers in several European countries at the expense of juice from concentrate (AIJN 2018; Płocharski et al. 2019). In the literature, no special attention was paid to differentiate between suitability of apples for production of direct cloudy juices or concentrated apple juice. The most important in cloudy juice production is the quality of the final product (it must be a premium product, to compete with cheaper clear juice produced from concentrate) (AIJN 2018). Referring to the current tendency of increased consumption of cloudy apple juices, it is worth to differentiate between the two categories and report results in particular on juice yield and compare basic quality parameters of the products obtained from scab resistant cultivars. 


\section{MATERIAL AND METHODS}

Work on scab resistant apple suitability for juice production was continued for three successive years: 2006, 2007, and 2008. The number of cultivars tested each year was between 24 and 27, depending on the raw material availability in the Experimental Orchard of the Research Institute of Horticulture in Skierniewice, Poland. Most cultivars were of Central European origin ( 8 from the Czech Republic, 8 from Germany, and 5 from Poland) (Table 1). Laboratory method of juice pressing was used to estimate the juice yield (Banaszczyk \& Płocharski 1993). Apples picked at the commercial maturity stage were delivered to cold storage facilities of the Department of Storage and Processing at a minimal quantity of $15 \mathrm{~kg}$, and after sorting to obtain representative samples, were processed within a few days after picking. For laboratory test, about $5 \mathrm{~kg}$ of apples was disintegrated using Fryma perforated disc mill (during the disintegration of apples, ascorbic acid solution was intentionally not

Juice without mash enzymation added to prevent browning). The mash was mixed and 4 test samples $200 \mathrm{~g}$ each was weighed. Considering the possibility of both clear and cloudy juice production, mash was pressed with and without enzymation. For clear juice production, two samples of the mash were depectinized using Rohapect MA PLUS (at dose $100 \mathrm{~g} \cdot \mathrm{t}^{-1}$ ), kindly provided by $A B$ Enzymes. Depectinization was carried out at $20{ }^{\circ} \mathrm{C}$ for 1 hour. After enzymatic treatment, the samples were pressed using Instron 4303 texture analyzer equipped with facility for juicing (Fig. 1). The total pressing time was 15 minutes. Obtained raw juice was depectinized with Rohapect $10 \mathrm{~L}$ (at dose $20 \mathrm{~g} \cdot 1000 \mathrm{~L}^{-1}, \mathrm{AB}$ Enzymes) at $50^{\circ} \mathrm{C}$ for 1 hour. Juices were heated up to $95^{\circ} \mathrm{C}$ for 5 minutes followed by centrifugation at 30,000 g (Sigma 3K30) for 20 minutes.

For cloudy juice production, two samples of the mash were pressed under the same conditions as clear juice but without depectinization and were directly analyzed. Juice yield was calculated from the weight of pomace obtained after pressing.

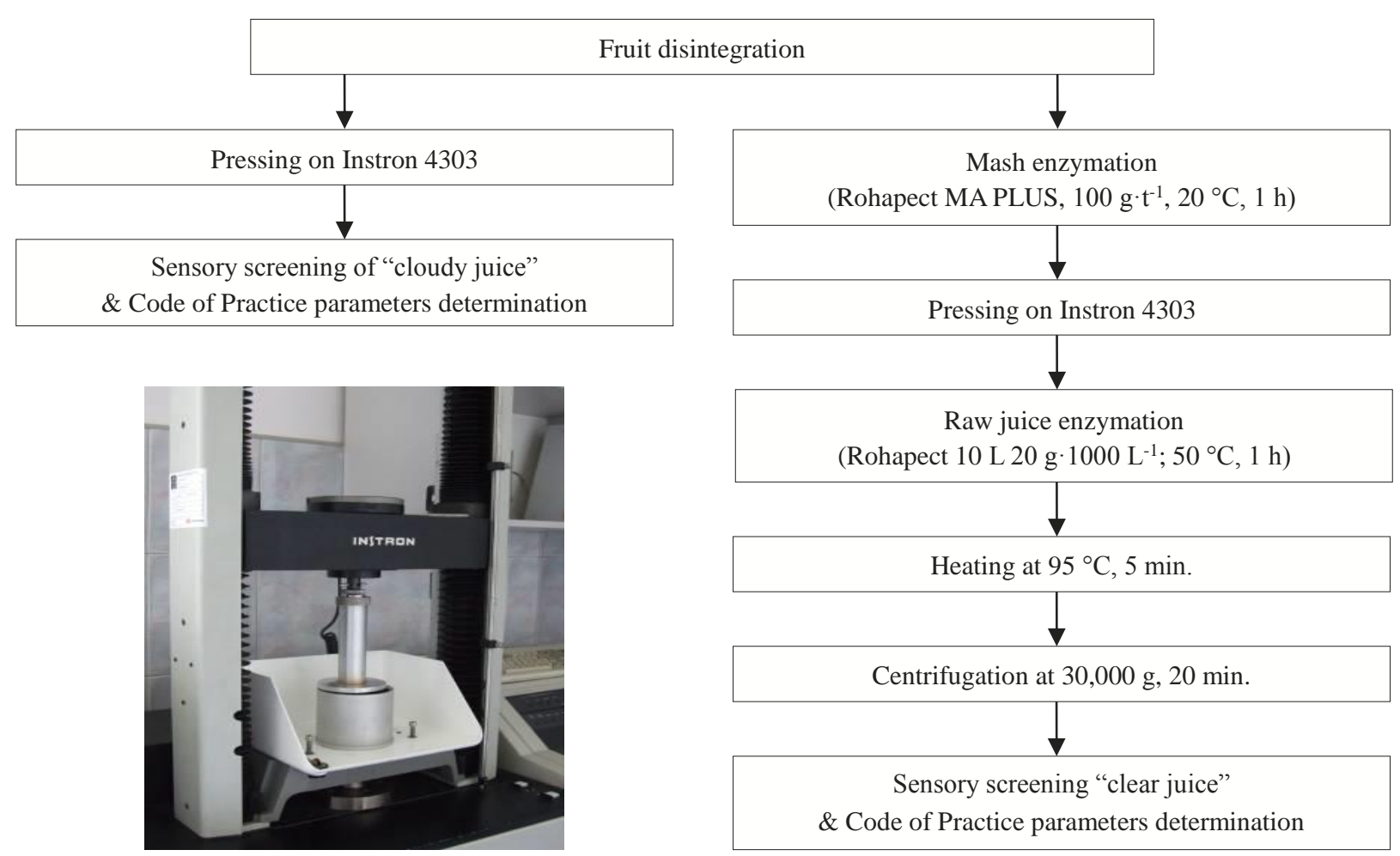

Figure 1. Clear and cloudy juice technology used on laboratory scale 
Obtained cloudy and clear juices were analyzed for basic qualitative characteristics such as soluble solids, titratable acidity; juices were also analyzed organoleptically. Soluble solids were determined by refractometric method (IFU 8) using RE 50 refractometer (Mettler-Toledo, Japan), results were expressed in percentage. Titratable acidity (method IFU 3) was measured by titration unit DL 58 (Mettler-Toledo, Switzerland). Results were expressed as anhydrous citric acid in $\mathrm{g} \cdot \mathrm{L}^{-1}$. Obtained results were compared with the respective Code of Practice values (AIJN 2012).

For sensory evaluation, clear and cloudy juices obtained during experiments were judged by four people experienced in sensory analysis. The worked out score sheet contained 6 quality parameters on a 10 point scale to allow the selection of juices with the most desirable sensory characteristics. 1. Aroma (undesirable - highly desirable)

2. Color (undesirable - highly desirable)

3. Taste-acceptability (undesirable-highly desirable)

4. Taste (sweet - sour balance)

5. Astringency (indiscernible - intensive)

6. Overall quality (very low - very high)

\section{Statistical analyses}

Each analysis was performed in tree independent season, so the results in the tables and graph represent the mean of these season. The results were analyzed by one-way analysis of variance (ANOVA) using the Statistica 12 software package (StatSoft, Inc., Tulsa, USA). The significance of the differences between sampling dates was estimated with Tukey's HSD test at $p=0.05$. To assess the impact of the variables, the cultivar was considered as the source of variation. Data obtained in sensory evaluation were processed and evaluated with the Principal Component Analysis (PCA) using Statistica 6.0 software.

\section{RESULTS AND DISCUSSION}

\section{Juice yield and basic juice characteristics}

Pressing yield, irrespectively of the technology used, depends on the apples' ripeness, cultivar characteristics, harvest season, and agricultural practices the highest juice yields are obtained for freshly picked, ripe fruit (Markowski 2000). Considering the above, to obtain comparable data and to avoid postharvest changes in fruit quality (even at the expense of aroma deficiency), fruits were processed shortly after harvest, thus the data represent well the effect of the harvest season and cultivar characteristic. Pressing of apple mash without enzymation showed very high variability between the cultivars investigated - the lowest values (below 70\%) were obtained for 'Renora' and 'Retina' (Fig. 2).

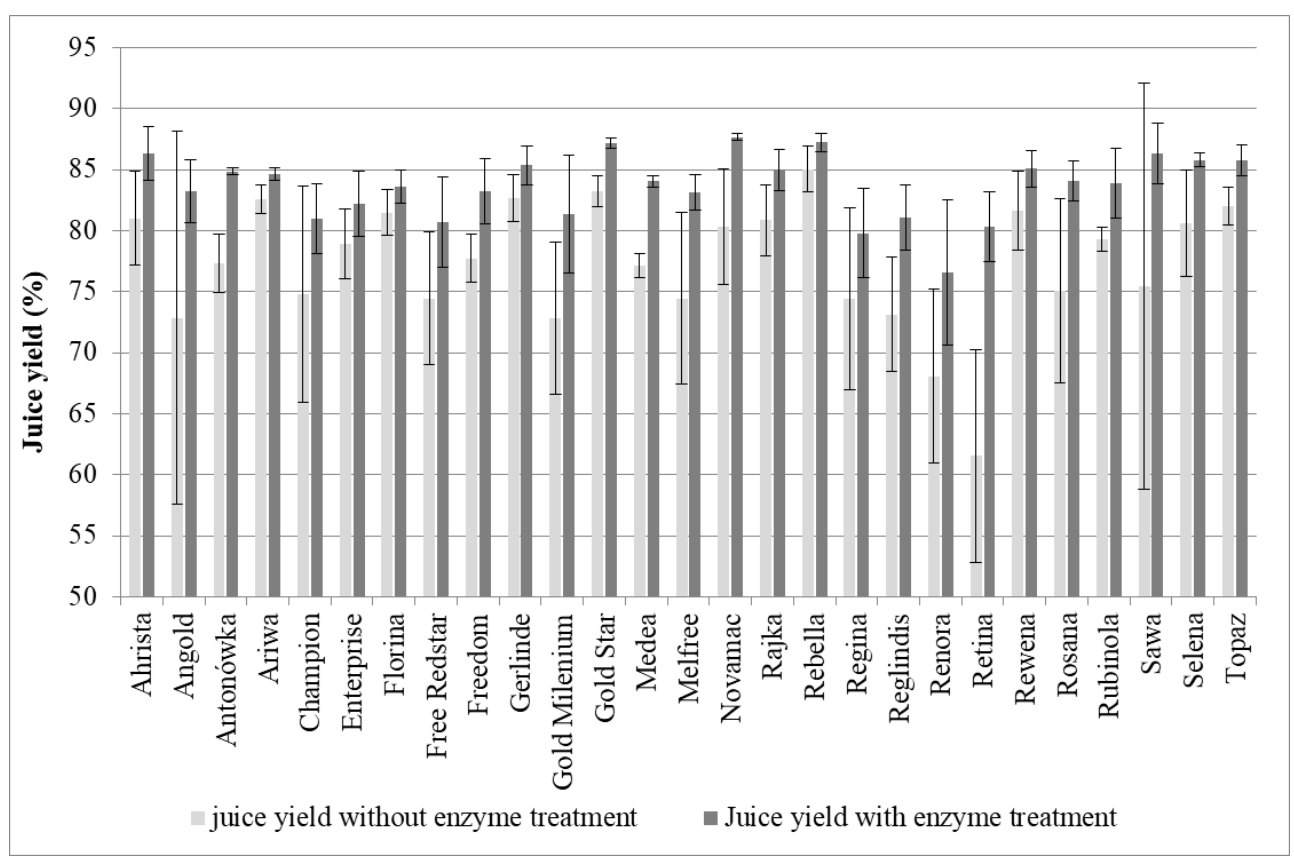

Figure 2. Juice yield during pressing with or without enzyme mash treatment (averages for 3 investigated seasons; bars depict a standard deviation between seasons) 
There were nine cultivars ('Angold', 'Champion', 'Gold Milenium', 'Melfree', 'Regine', 'Renora', 'Retina' 'Rosana', and 'Sawa') with high variability of juice yield between the seasons. For most cultivars, yield was above $80 \%$, which is, beside high acidity and soluble solids content, a prerequisite for the recommendation of raw material for industrial processing (Ebert 2017). Juice yield without enzyme treatment above $80 \%$, in all three seasons, was obtained for 'Ariwa', 'Florina', 'Gerlinde', 'Gold Star', 'Rebella', 'Rewena', and 'Topaz'. High yields were also obtained for 'Ahrista', 'Novamac', 'Rajka', and 'Selena', however, with a rather high variability between the seasons.

Enzymation of the mash resulted in increasing of the juice yield in all the cultivars. However, there was a very high negative relationship $\left(r^{2}=\right.$ 0.8403 ) between juice yields during pressing without enzyme treatment and the gain due to enzymatic treatment (Fig. 3).

In a few cases (cultivars 'Gold Star', 'Novamac', and 'Rebella'), juice yield after mash enzymation was over $87 \%$. Other cultivars, with an exception of 'Regine' and 'Renora', fulfilled the requirement of a minimum $80 \%$ yield. A cultivar with highly variable yield after enzymation, depending on the season, was 'Renora' (date not shown). High yields either of cloudy or clear juice are important considering the economy of the process. However, in the case of low yields, in practice, the pressing is repeated after the addition of water to the press cake, disintegration, and enzymation.
The juice thus obtained might be used for the production of concentrated juice or beverages, but not for cloudy or clear direct juice. Enzymation of the juice obtained is necessary for concentrated juice production, however, enzymation of the mash is an option, and it may be anticipated that it may not be profitable if the gain of additional juice would be below 3\% (cultivars 'Ariva', 'Florina', 'Gerlinde', and 'Rebella'), especially at low raw material prices. Such cultivars considering the economy of pressing might be especially preferable for cloudy juice production on the contrary to, e.g., 'Retina', characterized by low cloudy juice yield. Juice yield (not indicated if clear or cloudy) of several scab resistant apple cultivars (including those covered in our experiment - 'Reglindis', 'Renora', 'Rewena', and 'Florina') were investigated by Fischer et al. (2001), who also found high cultivar variation in this parameter (in the range of $56.3 \%$ to $76.4 \%$ ). They obtained low juice yields for 'Florina' $(62.8 \%)$, which irrespectively of the season, in our experiments was classified as high cloudy or clear juice yielding cultivar (over $80 \%$ ). It is worth mentioning that the method of pressing using Instron, although employing small samples, is highly reliable due to precise control of pressing force and time. On the industrial scale using Bucher press, apple juice yields are about $85 \%$, which can reach $92 \%$ with the use of enzymes and leaching (Saravacos \& Kostaropoulos 2016).

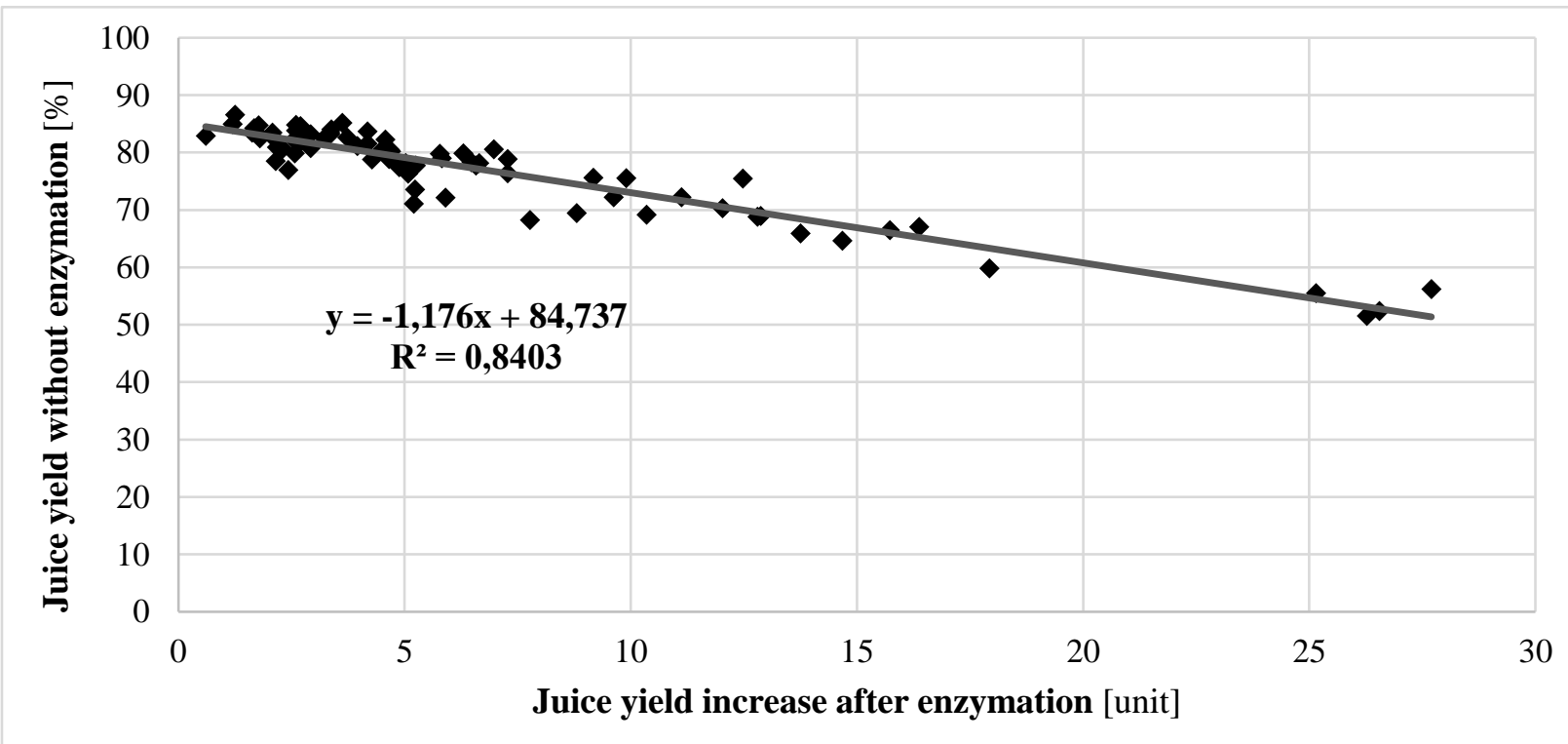

Figure 3. Effect of enzymation on juice yield of scab resistant cultivars (the point means apple cultivar each season) 
In general, it may be said that in the case of cloudy juice, yields for most cultivars were usually in the range $75-80 \%$, whereas after enzymatic treatment, pressing yields exceeded the value $80 \%$ suggested by Ebert (2017) as profitable for the industry.

Soluble solids content and titratable acidity are considered important quality parameters because of their effect on sensory perception of apple juices and are highly significant considering the economy of concentrated juice production. According to the AIJN Code of Practice for direct apple juices soluble solids content should be a minimum of $10 \%$. This requirement was fulfilled in the investigated seasons for all the cultivars with an exception of 'Antonovka' in 2008 (in fact this was the season in which most cultivars had lower soluble solids content, than in the previous seasons). Cultivars characterizing with significantly higher soluble solids content than all the others were 'Regine' and 'Topaz' (in two of the three investigated seasons above 14\%) (Table 1). Rich in soluble solids content (close to 13\%) were also 'Champion', 'Enterprise', 'Gold Milenium', 'Melfree', 'Renora', and 'Rubinola'. Juices after enzymatic treatment of the mash contained slightly more soluble solids (by $0.39 \%$ ) than the cloudy juices and the correlation coefficient between measurements in cloudy and clear juices was 0.9576 .

Table 1. Cultivar differences in soluble solids and acidity of directly pressed apple juice without enzymation (average for 3 seasons)

\begin{tabular}{|c|c|c|c|c|c|}
\hline Cultivar & CODE & Origin & $\begin{array}{c}\text { Soluble solids } \\
{[\%]} \\
\end{array}$ & $\begin{array}{c}\text { Acidity } \\
{\left[\mathrm{g} \cdot \mathrm{L}^{-1}\right]} \\
\end{array}$ & $\begin{array}{c}\text { Soluble } \\
\text { solids/acidity } \\
\end{array}$ \\
\hline 'Ahrista' & AHR & Germany & $11.38 \pm 0.83$ & $5.45 \pm 1.38$ & 20.9 \\
\hline 'Angold' & ANG & Czech Republic & $12.85 \pm 1.27$ & $5.17 \pm 1.97$ & 24.9 \\
\hline 'Antonovka' & ANT & Russia & $10.03 \pm 1.55$ & $10.35 \pm 0.89$ & 9.7 \\
\hline 'Ariwa' & ARI & Switzerland & $12.14 \pm 0.41$ & $5.21 \pm 0.86$ & 23.3 \\
\hline 'Champion' & $\mathrm{CHA}$ & Czech Republic & $13.41 \pm 0.61$ & $3.1 \pm 1.11$ & 43.3 \\
\hline 'Enterprise' & ENT & USA & $13.50 \pm 0.33$ & $7.22 \pm 1.75$ & 18.7 \\
\hline 'Florina' & FLO & France & $12.54 \pm 1.30$ & $5.13 \pm 1.21$ & 24.4 \\
\hline 'Free Redstar' & FRS & Poland & $12.19 \pm 1.28$ & $6.22 \pm 2.27$ & 19.6 \\
\hline 'Freedom' & FRM & USA & $12.41 \pm 0.91$ & $7.18 \pm 1.63$ & 17.3 \\
\hline 'Gerlinde' & GER & Germany & $12.75 \pm 1.18$ & $7.12 \pm 2.61$ & 17.9 \\
\hline 'Gold Milenium' & GOM & Poland & $13.28 \pm 0.19$ & $4.43 \pm 1.11$ & 30.0 \\
\hline 'Gold Star' & GS & Czech Republic & $11.62 \pm 0.62$ & $4.78 \pm 1.16$ & 24.3 \\
\hline 'Medea' & MDA & Poland & $12.52 \pm 0.68$ & $6.01 \pm 2.83$ & 20.8 \\
\hline 'Melfree' & MEL & Poland & $13.34 \pm 0.96$ & $5.76 \pm 1.80$ & 23.2 \\
\hline 'Novamac' & $\mathrm{NOM}$ & Canada & $11.79 \pm 0.60$ & $7.19 \pm 0.34$ & 16.4 \\
\hline 'Rajka' & RAJ & Czech Republic & $13.00 \pm 1.56$ & $5.59 \pm 1.48$ & 23.3 \\
\hline 'Rebella' & RBL & Germany & $12.91 \pm 1.50$ & $7.73 \pm 2.45$ & 16.7 \\
\hline 'Regine' & RGN & Germany & $13.90 \pm 1.13$ & $8.26 \pm 2.02$ & 16.8 \\
\hline 'Reglindis' & REG & Germany & $12.67 \pm 0.78$ & $11.07 \pm 2.17$ & 11.4 \\
\hline 'Renora' & RNR & Germany & $13.24 \pm 0.67$ & $9.25 \pm 1.30$ & 14.3 \\
\hline 'Retina' & RET & Germany & $12.45 \pm 0.82$ & $4.77 \pm 1.76$ & 26.1 \\
\hline 'Rewena' & REW & Germany & $12.59 \pm 0.80$ & $9.22 \pm 2.46$ & 13.7 \\
\hline 'Rosana' & ROS & Czech Republic & $11.54 \pm 0.66$ & $7.84 \pm 2.74$ & 14.7 \\
\hline 'Rubinola' & $\mathrm{RBN}$ & Czech Republic & $13.36 \pm 1.00$ & $6.1 \pm 0.70$ & 21.9 \\
\hline 'Sawa' & SAW & Poland & $13.07 \pm 0.47$ & $7.41 \pm 1.57$ & 17.6 \\
\hline 'Selena' & SEL & Czech Republic & $11.28 \pm 0.73$ & $3.94 \pm 1.42$ & 28.6 \\
\hline 'Topaz' & TOP & Czech Republic & $13.82 \pm 0.62$ & $7.81 \pm 2.04$ & 17.7 \\
\hline
\end{tabular}

Means \pm SD; probability of F statistic from ANOVA for soluble solids and acidity: $<0.00$ 
Titratable acidity, expressed as anhydrous citric acid, which represents all the organic acids present in the juice, according to the AIJN Code of Practice cannot be lower than $2.2 \mathrm{~g} \cdot \mathrm{L}^{-1}$. This requirement was met for all the cultivars. The average value of titratable acidity in cloudy juices was $6.7 \mathrm{~g} \cdot \mathrm{L}^{-1}$, however, on the contrary to the soluble solids content, there was a very high variability of this parameter between the cultivars and also between the seasons. 'Champion' cultivar had the lowest acidity - over 3 times less than the richest 'Reglindis'. Low acidity cultivars (below $5 \mathrm{~g} \cdot \mathrm{L}^{-1}$ ), were also 'Gold Milenium', 'Gold Star', 'Retina', and 'Selena'. In clear juices, due to enzymatic treatment, acidity slightly increased (on average by 7\%). Considering the differences in the ranges of soluble solids and acidity, it becomes obvious that the ratio of both constituents primarily depends on the content of organic acids.

Malic acid that dominates in apple fruits is also an important substrate in fruit respiration, and during fruit ripening on the tree and during storage, it is metabolized, changing the proportion of soluble solids to acids. To changes in proportion contributes also to degradation of sucrose and starch accompanied by the changes in fruit firmness, which influences juice yield (Markowski 2000).

Bryk et al. (2013) checked the quality and storability of several cultivars including 'Enterprise', 'Free Redstar', 'Melfree', 'Rajka', 'Rewena' 'Rubinola', and 'Topaz', and indicated that for most of them, an optimal storage life was four months. This information is important considering the possibility of producing high-quality direct juice for several months after harvest. High acidity apples should rather be used for cloudy juice production after storage to gain more balanced soluble solids to acidity ratio. Some low acidity cultivars characterized by very high soluble solids content and high relative density ('Gold Milenium', 'Champion') may be used for juice production in a mixture with high acidity cultivars.

Our results for soluble solids and acidity are highly comparable with the data published by Höhne (2008), who beside information on the agrotechnical value of 14 cultivars reported on soluble solids and acids content in fresh fruit covering among others 'Ahrista', 'Enterprise', 'Florina', 'Gerlinde', 'Rebella', 'Regine', 'Retina', 'Rubinola', and 'Topaz'. The correlation coefficient between our results and those reported by Höhne (2008) for the above cultivars for soluble solids was 0.9427 , whereas for acidity 0.8206 . Ebert (2017) considering the suitability of scab resistant apple cultivars for juice production also reported on soluble solids and acidity content in 'Angold', 'Enterprise', 'Rebella', 'Rewena', and 'Topaz' and our results agree with his data.

\section{Sensory analysis}

Averages for the years indicated that there were large differences between cultivars in the overall quality of cloudy (the range 3.3 to 7.5 in 10-points scale) and clear juices (the range 2.5 to 7.7 ) (Table 2). As expected, the lowest scores in both products received 'Antonovka' due to lack of balance in taste (both acceptability and the sweet-sour balance). Out of the tested cloudy juices, 4 cultivars received 7 or slightly higher scores in 'overall quality' evaluation - these were: 'Ahrista', 'Gold Milenium', 'Rajka' and 'Rubinola'. Assuming that a good product should score at least 6 points on a 10 points scale, an acceptable raw material for cloudy juice production may be considered: 'Angold', 'Ariwa', 'Champion', 'Enterprise', 'Florina', 'Gerlinde', and 'Medea'. Above mentioned cultivars were also suitable for clear juice production, however 'Champion', 'Gerlinde', and 'Rubinola' received scores slightly below 6 points, whereas slightly above 6 points were scored 'Retina' and 'Selena'. Suitability of cultivars for cloudy and clear juices' production depended primarily on taste perception (acceptability and sweet-sour balance). The correlation coefficient between taste acceptability and overall quality for both kinds of juices was above 0.90 and in the case of sweetsour balance/overall quality above 0.75 (data not shown). A strong influence on the overall quality of cloudy and clear juices had also astringency, however, this characteristic was perceived as a negative criterion. Ebert (2017) mentioned that juice should be appreciated also for the aroma. 
In cloudy juices, there was a strong correlation between overall quality and aroma $(\mathrm{r}=0.545)$, all cultivars were scored above 5.3 points but the most aromatic juices were obtained from 'Ahrista' and 'Gerlinde' (respectively 7.1 and 7.2 points). In clear juices, due to enzymatic and high-temperature treatment, aroma did not correlate with the overall quality. It is obvious why in normal practice during clear juice production, raw juice undergoes dearomatization before clarification and filtration, and aromas are added to the final product. Color of freshly pressed apple juices depends on many factors among others on the amount of specific phenolics substrates and polyphenol oxidase activity (PPO). In this experiment, ascorbic acid was not added during disintegration of the mash, to prevent browning. Therefore, in the case of cloudy juices, the most acceptable color the juice had obtained was from 'Champion' cultivar, which according to Podsędek et al. (2000) has very low polyphenol oxidase activity and relatively low catechin and chlorogenic acid contents in fresh fruit. According to Kołodziejczyk et al. (2010), low polyphenol oxidase activity in fresh fruit beside 'Champion' show also 'Rebella', 'Topaz', 'Rewena', 'Enterprise', and 'Gerlinde', on the opposite to 'Angold', 'Selena', and 'Gold Milenium', which were characterized with high PPO activity. Our results show that in clear juices, irrespective of the processing season, 'Champion' was judged as unacceptable in color (on average only 2.8 points), estimated as not clear enough. It is worth mentioning that there was a negative correlation between the color of cloudy and clear juices $(r=-0.496)$.

Table 2. Sensory results on 10 point scale for cloudy and clear juice (averages for 3 investigated seasons)

\begin{tabular}{|c|c|c|c|c|c|c|c|c|}
\hline \multirow{2}{*}{ Cultivar } & \multicolumn{4}{|c|}{ Cloudy juice } & \multicolumn{4}{|c|}{ Clear juice } \\
\hline & Aroma & Color & Taste* & Overall quality & Aroma & Color & Taste* & Overall quality \\
\hline 'Ahrista' & $7.1 \pm 0.7$ & $5.7 \pm 0.3$ & $7.3 \pm 0.3$ & $7.5 \pm 0.2$ & $7.5 \pm 1.5$ & $7.0 \pm 0.5$ & $6.8 \pm 0.9$ & $6.6 \pm 0.2$ \\
\hline 'Angold' & $6.3 \pm 0.5$ & $3.5 \pm 0.5$ & $6.8 \pm 0.5$ & $6.3 \pm 0.8$ & $6.5 \pm 1.3$ & $6.2 \pm 0.5$ & $6.3 \pm 0.7$ & $6.4 \pm 0.6$ \\
\hline 'Antonovka' & $5.9 \pm 1.4$ & $4.4 \pm 0.8$ & $3.4 \pm 1.5$ & $3.3 \pm 0.8$ & $6.8 \pm 1.4$ & $6.8 \pm 1.7$ & $2.6 \pm 1.1$ & $2.5 \pm 0.1$ \\
\hline 'Ariwa' & $6.1 \pm 2.0$ & $4.4 \pm 1.1$ & $6.7 \pm 0.6$ & $6.2 \pm 0.6$ & $6.2 \pm 1.3$ & $6.2 \pm 0.8$ & $6.4 \pm 0.4$ & $6.5 \pm 0.5$ \\
\hline 'Champion' & $6.0 \pm 0.4$ & $6.8 \pm 0.3$ & $7.0 \pm 0.4$ & $6.7 \pm 0.3$ & $5.8 \pm 0.8$ & $2.8 \pm 0.7$ & $6.1 \pm 0.4$ & $5.4 \pm 0.8$ \\
\hline 'Enterprise' & $5.5 \pm 0.7$ & $4.8 \pm 1.5$ & $6.6 \pm 0.5$ & $6.3 \pm 0.2$ & $6.5 \pm 1.1$ & $6.7 \pm 1.0$ & $6.5 \pm 0.7$ & $6.5 \pm 0.5$ \\
\hline 'Florina' & $6.1 \pm 0.9$ & $5.0 \pm 0.2$ & $6.4 \pm 0.7$ & $6.1 \pm 1.0$ & $6.9 \pm 0.5$ & $7.0 \pm 0.2$ & $6.6 \pm 0.8$ & $6.7 \pm 0.3$ \\
\hline 'Free Redstar' & $5.4 \pm 0.4$ & $4.7 \pm 0.4$ & $4.4 \pm 0.9$ & $3.9 \pm 0.5$ & $5.9 \pm 1.7$ & $7.8 \pm 1.0$ & $5.9 \pm 0.8$ & $5.8 \pm 1.6$ \\
\hline 'Freedom' & $6.0 \pm 0.6$ & $5.4 \pm 1.6$ & $5.6 \pm 0.1$ & $5.5 \pm 0.6$ & $6.8 \pm 0.8$ & $6.5 \pm 0.8$ & $5.0 \pm 0.4$ & $4.9 \pm 0.5$ \\
\hline 'Gerlinde' & $7.2 \pm 0.3$ & $4.9 \pm 0.4$ & $6.9 \pm 0.5$ & $6.6 \pm 0.4$ & $6.6 \pm 1.8$ & $6.0 \pm 1.4$ & $5.8 \pm 0.8$ & $5.5 \pm 1.5$ \\
\hline 'Gold Milenium' & $6.7 \pm 0.6$ & $3.3 \pm 0.4$ & $7.6 \pm 0.2$ & $7.0 \pm 0.0$ & $6.8 \pm 1.1$ & $7.5 \pm 0.3$ & $7.3 \pm 0.3$ & $7.7 \pm 0.0$ \\
\hline 'Gold Star' & $6.7 \pm 0.8$ & $5.1 \pm 0.1$ & $5.5 \pm 0.3$ & $5.8 \pm 0.6$ & $6.3 \pm 1.8$ & $6.9 \pm 0.6$ & $6.4 \pm 0.1$ & $5.9 \pm 0.2$ \\
\hline 'Medea' & $6.0 \pm 0.8$ & $4.4 \pm 1.3$ & $6.6 \pm 1.0$ & $6.6 \pm 0.3$ & $6.1 \pm 1.5$ & $6.9 \pm 0.1$ & $6.8 \pm 0.1$ & $6.5 \pm 0.5$ \\
\hline 'Melfree' & $5.5 \pm 0.7$ & $4.3 \pm 1.1$ & $6.0 \pm 0.4$ & $5.8 \pm 0.6$ & $6.4 \pm 1.5$ & $7.1 \pm 0.8$ & $5.5 \pm 1.8$ & $5.1 \pm 2.1$ \\
\hline 'Novamac' & $5.9 \pm 0.7$ & $4.2 \pm 1.1$ & $4.6 \pm 0.7$ & $4.7 \pm 1.0$ & $6.4 \pm 1.7$ & $4.4 \pm 1.4$ & $5.4 \pm 1.2$ & $5.5 \pm 0.8$ \\
\hline 'Rajka' & $6.6 \pm 0.5$ & $5.8 \pm 1.5$ & $7.0 \pm 0.5$ & $7.1 \pm 0.7$ & $6.1 \pm 1.8$ & $6.3 \pm 0.9$ & $6.2 \pm 1.1$ & $6.4 \pm 1.3$ \\
\hline 'Rebella' & $6.3 \pm 1.4$ & $4.7 \pm 1.4$ & $5.5 \pm 1.2$ & $5.2 \pm 1.9$ & $5.0 \pm 1.2$ & $3.3 \pm 0.6$ & $4.9 \pm 0.6$ & $4.7 \pm 0.4$ \\
\hline 'Regine' & $5.3 \pm 0.9$ & $5.1 \pm 0.6$ & $3.4 \pm 0.1$ & $3.3 \pm 0.1$ & $6.3 \pm 0.3$ & $6.6 \pm 0.8$ & $3.1 \pm 1.0$ & $3.6 \pm 1.2$ \\
\hline 'Reglindis' & $6.0 \pm 1.0$ & $4.7 \pm 1.4$ & $5.1 \pm 1.6$ & $5.1 \pm 2.0$ & $5.2 \pm 2.8$ & $6.9 \pm 1.3$ & $4.5 \pm 2.1$ & $4.5 \pm 1.5$ \\
\hline 'Renora' & $6.3 \pm 0.7$ & $3.9 \pm 0.7$ & $4.7 \pm 1.0$ & $4.0 \pm 0.6$ & $6.2 \pm 1.1$ & $7.0 \pm 0.8$ & $5.0 \pm 0.5$ & $5.3 \pm 0.5$ \\
\hline 'Retina' & $6.2 \pm 0.5$ & $2.8 \pm 0.5$ & $5.7 \pm 0.6$ & $5.6 \pm 0.9$ & $6.1 \pm 1.5$ & $7.0 \pm 0.8$ & $6.6 \pm 0.6$ & $6.4 \pm 1.7$ \\
\hline 'Rewena' & $6.7 \pm 1.3$ & $5.5 \pm 0.9$ & $4.6 \pm 1.3$ & $4.7 \pm 1.1$ & $6.5 \pm 1.1$ & $5.9 \pm 0.7$ & $3.7 \pm 0.2$ & $3.7 \pm 0.4$ \\
\hline 'Rosana' & $6.1 \pm 1.7$ & $5.2 \pm 0.6$ & $5.1 \pm 0.8$ & $5.1 \pm 0.4$ & $6.5 \pm 1.1$ & $6.1 \pm 1.4$ & $5.5 \pm 10$ & $5.8 \pm 1.1$ \\
\hline 'Rubinola' & $6.8 \pm 0.9$ & $7.7 \pm 0.5$ & $6.4 \pm 1.1$ & $7.4 \pm 0.4$ & $6.7 \pm 0.4$ & $4.3 \pm 0.8$ & $5.6 \pm 0.6$ & $5.9 \pm 0.7$ \\
\hline 'Sawa' & $6.4 \pm 1.5$ & $5.1 \pm 1.1$ & $5.9 \pm 1.7$ & $5.7 \pm 1.6$ & $7.0 \pm 1.3$ & $6.2 \pm 1.7$ & $5.3 \pm 1.5$ & $5.3 \pm 1.1$ \\
\hline 'Selena' & $6.6 \pm 0.4$ & $4.4 \pm 1.4$ & $5.7 \pm 1.7$ & $5.3 \pm 1.6$ & $6.5 \pm 1.6$ & $6.3 \pm 0.4$ & $6.8 \pm 0.4$ & $6.5 \pm 0.6$ \\
\hline 'Topaz' & $6.8 \pm 1.1$ & $5.2 \pm 1.5$ & $5.9 \pm 0.7$ & $5.8 \pm 0.9$ & $6.7 \pm 0.6$ & $6.2 \pm 1.5$ & $5.5 \pm 1.0$ & $5.8 \pm 0.6$ \\
\hline
\end{tabular}


PCA analysis showed that in 2006, there was a strict differentiation between sensory attributes of cloudy juices. The cultivars in a group marked by a red ellipse on Fig. 4 ('Regine', 'Rebella', 'Reglindis', 'Rewena', 'Antonovka', 'Renora', 'Rosana', 'Selena', 'Free Redstar') received low-quality scores and cannot be used for cloudy juices' production as a single cultivar. Juices from other cultivars, in general, were acceptable and could be used for processing as single cultivar juices. However, the high sensory quality was found for 'Champion', 'Rajka', 'Ahrista', and 'Sawa' cultivars. The picture of cloudy juices in season 2007 was not so clear (data are not shown), however, it can be said that there was a group of cultivars with high sensory quality. These were: 'Champion', 'Rajka', 'Florina', 'Gold Milenium', 'Gerlinde', 'Selena', and 'Ariwa'. The picture becomes more complicated when comparing obtained results with sensory data for the 2008 season (Fig. 5).

In the picture, blue solid dots mark the cultivars processed on a semi technological scale. For some cultivars, such as 'Renora', 'Regine', 'Antonovka', 'Free Redstar' low sensory scores were obtained irrespective of the processing season, whereas for others, the effect of the season was obvious, manifested by high variability of different characteristics. Nevertheless some conclusions concerning cultivars' suitability for cloudy juices' production may be drawn. Taking into consideration the data from three processing seasons, it can be said that cloudy juices from 'Champion', 'Gold Milenium', 'Rajka', and 'Ariwa' obtained higher sensory scores than other cultivars and can be regarded as a good raw material for the production of this commodity.

Considering the changes in market requirements, it has been justified to update the approach to the suitability of apples for juice production, covering also clear and cloudy juices. On the contrary to apples for concentrate production, the raw material for cloudy juices and smoothies may characterize with parameters closer to those typical for dessert apples, which dominate in Poland. Moreover, by controlling fruit ripeness degree, producer of direct juice may influence the sugar to acids ratio, shaping to some extent sensory parameters of the obtained product. Simultaneous processing of many cultivars differing in processing parameters is a normal procedure on a large scale. In the selection of cultivars for industrial orchards, highly important is not only the fruit quality but also the fruit production profitability. In our case, cultivars 'Enterprise' and 'Rubinola' were very suitable for processing, however, as claimed by Bryk and Kruczyńska (2011), they were not reliable in cropping. On the contrary, Czynczyk et al. (2011) considered that among others, 'Rubinola' is highly suitable for organic apple production. Suitability for organic production of several cultivars of apples is given in a report by Kruczyńska et al. (2017).

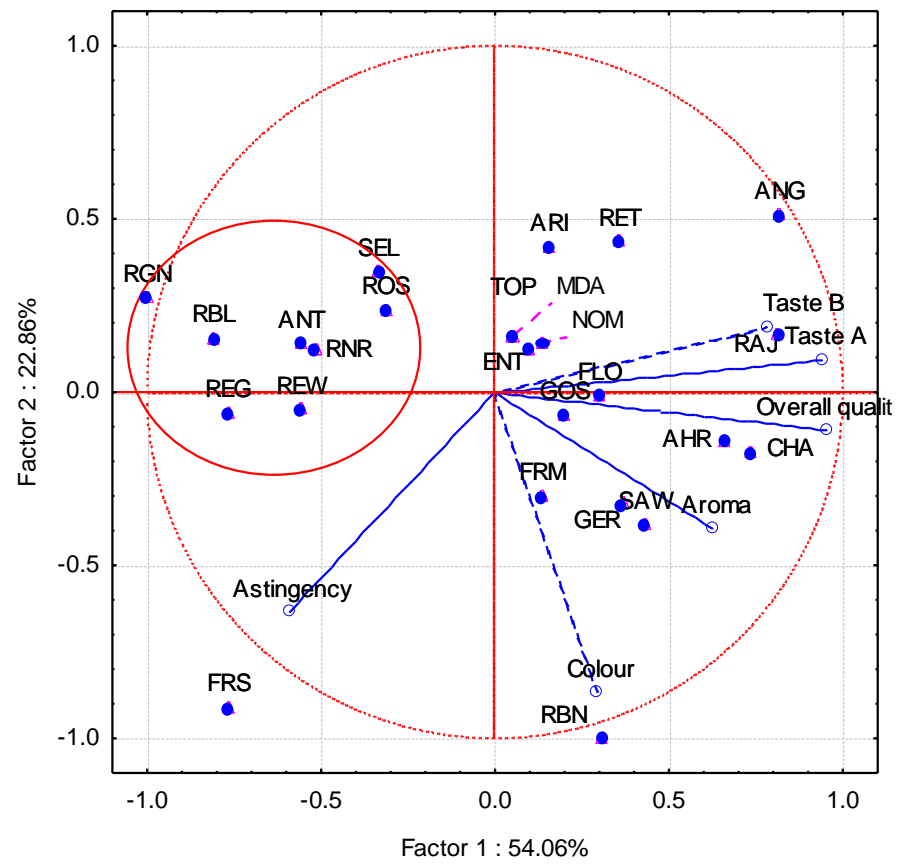

Figure 4. PCA projection of differences and similarities of sensory quality of cloudy juices in 2006 season; sensory characteristic $(\circ)$, apple cultivar $(\bullet)$. Abbreviations: Taste A (acceptability), Taste B (sour-sweet balance)

Code of cultivars: see Table 1 


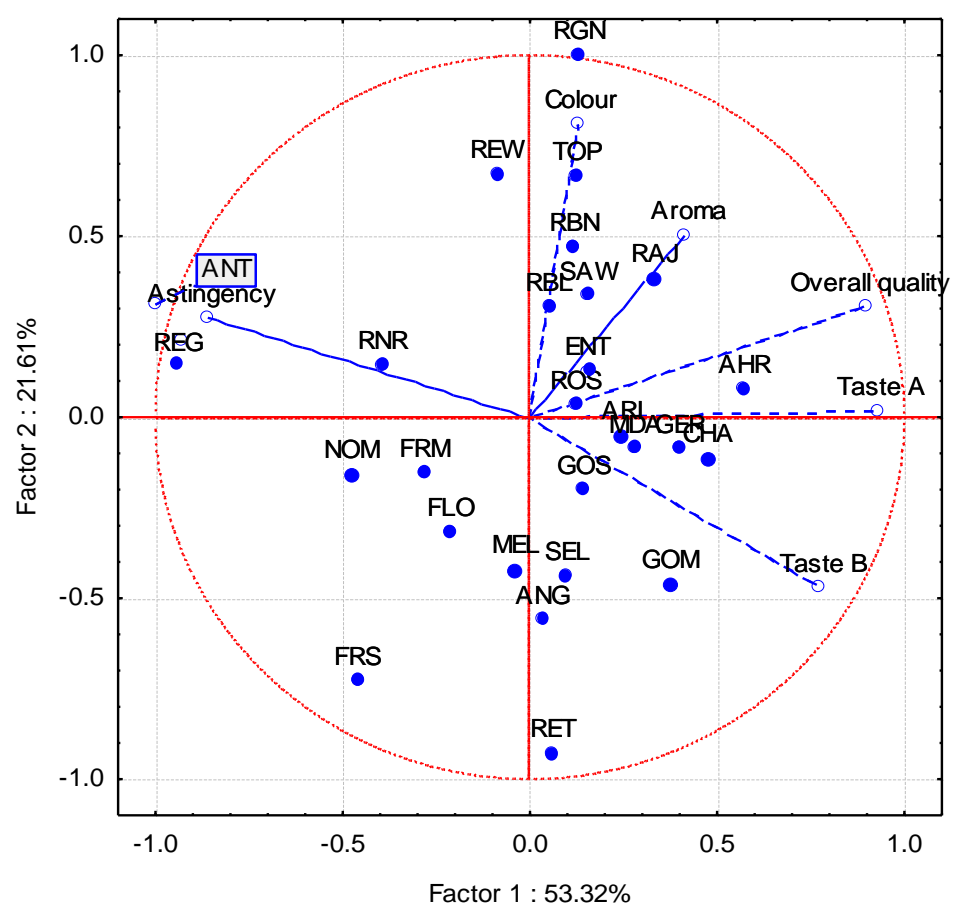

Figure 5. PCA projection of differences and similarities of sensory quality of cloudy juices in 2008 season Abbreviations: see Fig. 4.

\section{CONCLUSIONS}

Most studied cultivars fulfilled the requirements of the Code of Practice in respect to the investigated quality parameters of apple juice. For cloudy juice production, considering its quality highly suitable were 'Champion', 'Gold Milenium', 'Rajka', and 'Ariwa'. Because of low cloudy juice yield, the use of cultivars 'Renora' and 'Retina' may not be economically justified. Scab resistant cultivars that may be recommended for industrial orchards considering juice yield, quality parameters and opinion on fruit yield, were the following: 'Regine', 'Rebella', 'Sawa', and 'Topaz'. Cultivars 'Enterprise', 'Rewena', and 'Rubinola' may also be considered because of their suitability for processing into clear juice, but may require more attention during cultivation.

\section{Acknowledgments}

This work had been prepared within the "ISAFRUIT" project (Contract No. FP6-FOOD-CT-2006-016279). Project was financed by the European Commission under Thematic Priority 5 - Food Quality and Safety of the $6^{\text {th }}$ Framework Programme of RTD.

\section{REFERENCES}

AIJN 2012. Code of Practice. The Reference Guidelines. European Fruit Juice Association.

AIJN 2018. Liquid Fruit. Market Report. European Fruit Juice Association.

Banaszczyk J., Płocharski W. 1993. Laboratory method for the estimation of the juice yield of apples. Fruit Processing 3(1): 9-13.

Bryk H., Kruczyńska D. 2011. Possibilities in growing and protection of apple trees against diseases in organic orchards. Journal of Research and Application in Agricultural Engineering 56(3): 40-44. [in Polish with English abstract]

Bryk H., Kruczyńska D., Rutkowski K.P. 2013. Quality and storability of apples of some cultivars from organic orchard. Journal of Research and Application in Agricultural Engineering 58(3): 59-65. [in Polish with English abstract]

Commission Implementing Regulation (EU) No 543/2011 of 7 June 2011 laying down detailed rules for the application of Council Regulation (EC) No 1234/2007 in respect of the fruit and vegetables and processed fruit and vegetables sectors. Official Journal of the European Union L 157 of 15.6.2011. https://eur-lex.europa.eu/legal-content/EN/TXT/PDF/?uri=CELEX:32011R0543\&fr $\mathrm{om}=\mathrm{en}$ 
Council Directive 2001/112/EC of 20 December 2001 relating to fruit juices and certain similar products intended for human consumption. Official Journal of the European Communities L 10/58 of 12.1.2002. https://eur-lex.europa.eu/legal-content/EN/TXT/PDF/?uri=CELEX:32001L0112\&qi $\mathrm{d}=1552566298746 \&$ from $=\mathrm{EN}$

Czynczyk A., Bielicki P., Mika A., Krawiec A. 2011. A nine-year evaluation of several scab-resistant apple cultivars for organic fruit production. Journal of Fruit and Ornamental Plant Research 19(2): 87-97.

Directive 2012/12/EU of the European Parliament and of the Council of 19 April 2012 amending Council Directive 2001/112/EC relating to fruit juices and certain similar products intended for human consumption. Official Journal of the European Union L 115/1 of 27.4.2012. https://eur-lex.europa.eu/legal-content/EN/TXT/?uri=CELEX\%3A32012L0012

Ebert M.H. 2017. Conceptual considerations about the intensive cultivation of industry apples in Poland. XX International Symposium of Polish Association of Juice Producers (KUPS) "Juice with reference to challenges of global and national markets". May 17-19, 2017, Wisła, Poland.

Fischer M., Schüler W., Fischer C., Gerber H.-J. 2001. Eignung Pillnitzer Apfelsorten-Neuzüchtungen für die Herstellung von Verarbeitungsprodukten aus biologisch orientiertem Anbau. Flüssiges Obst 68: 20-24. [in German]

Fischer M., Fischer Ch. 2008. The Pillnitz Re-Series of apple cultivars - Do they hold promise -80 years of professional German fruit breeding 2008. Erwerbs-Obstbau 50(2): 63-67. DOI: 10.1007/s10341-008-0061-4.

Höhne F. 2008. Anbauwert neuer Tafelapfelsorten mit Schorfresistenz - Teil III Qualitätsparameter, Lagereignung und Zusammenfassung. Mitteilungen der Landesforschungsanstalt Mecklenburg Vorpommern. [in German] https://www.landwirtschaft-mv.de/serviceassistent/download? $\mathrm{id}=1579846$

Holb I.J. 2009. Fungal disease management in environmentally friendly apple production - a review. In: Lichtfouse E. (Ed.), Climate change, intercropping, pest control and beneficial microorganisms. Sustainable Agriculture Reviews 2: 219-292. DOI: 10.1007/978-90-481-2716-0_10.
IndexMundi 2019. Fresh apples production by country in MT. Source: United States Department of Agriculture. https://www.indexmundi.com/agriculture/?commodity=apples \&graph=production

Kołodziejczyk K, Milala J., Sójka M., Kosmala M., Markowski J. 2010. Polyphenol oxidase activity in selected apple cultivars. Journal of Fruit and Ornamental Plant Research 18(2): 51-61.

Kruczyńska D.E., Bielicki P., Pąśko M. 2017. Raport z wynikami badań dotyczących przydatności odmian jabłoni do ekologicznej produkcji. Research Institute of Horticulture, Skierniewice, 11 p. [in Polish] http://www.inhort.pl/files/program_wieloletni/PW_2015_2020_IO/spr_2017/3.4_2017_Rap ort_Odmiany_jabloni_eko.pdf

Markowski J. 2000. Wpływ stopnia dojrzałości owoców kilku odmian jabłek oraz dodatku kwasu askorbinowego podczas produkcji naturalnie mętnych soków jabłkowych na ich jakość i stabilność. Ph.D. Thesis. Research Institute of Pomology, Skierniewice, Poland, 110 p. [in Polish]

Markowski J., Baron A., Le Quéré J-M., Płocharski W. 2015. Composition of clear and cloudy juices from French and Polish apples in relation to processing technology. LWT - Food Science and Technology 62: 813-820. DOI: 10.1016/j.lwt.2014.11.048.

Markowski J., Płocharski W. 2018. Does industrial apple orchard may be profitable? Przemysł Fermentacyjny i Owocowo-Warzywny 62(10): 26-27. DOI: 10.15199/64.2018.10.3. [in Polish with English abstract]

Nosecka B. 2018. The market of concentrated apple juice in Poland. Przemysł Fermentacyjny i OwocowoWarzywny 62(4): 17-20. DOI: 10.15199/64.2018.4.2. [in Polish with English abstract]

Ozimek R. 2007. Industrial orchards - chance for apple juice concentrate producers. X International Symposium of Polish Association of Juice Producers (KUPS) "Perspectives of development of juice and fruit and vegetable industry”. May 9-11, 2007, Zakopane, Poland.

Płocharski W., Mieszczakowska-Frąc M., Rutkowski K.P., Konopacka D. 2019. Tradycyjne i innowacyjne kierunki zagospodarowania jabłek w Polsce. Research Institute of Horticulture, Skierniewice, $31 \mathrm{p}$. [in Polish] http://www.inhort.pl/files/program_wieloletni/PW_2015_2020_IO/spr_2019/Broszura_Plochar ski_2019_Tradycyjne_zad.3.5.pdf 
Podsędek A., Wilska-Jeszka J., Anders B., Markowski J. 2000. Compositional characterisation of some apple varieties. European Food Research and Technology 210: 268-272. DOI: $10.1007 / \mathrm{s} 002179900101$.

Regulation (EU) No 1308/2013 of the European Parliament and of the Council of 17 December 2013 establishing a common organisation of the markets in agricultural products and repealing Council Regulations (EEC) No 922/72, (EEC) No 234/79, (EC) No 1037/2001 and (EC) No 1234/2007. Official Journal of the European Union L 347/671 of 20.12.2013. https://eur-lex.europa.eu/legal-content/EN/TXT/PDF/?uri=CELEX:32013R1308\&fr $\mathrm{om}=\mathrm{EN}$
Saravacos G., Kostaropoulos A.E. 2016. Mechanical separation equipment. Handbook of food processing equipment, second edition. Food Engineering Series. Springer International Publishing, p. 268. DOI: 10.1007/978-3-319-25020-5.

Statistics Poland 2020. Production of agricultural and horticultural crops in 2019. Statistical information. GUS, Warsaw, Poland. https://stat.gov.pl/en/topics/agriculture-forestry/agricultural-and-horticultural-crops/production-of-agricultural-and-horticultural-crops-in-2019,2,4.html

Teleszko M., Nowicka P., Wojdyło A. 2016. Chemical, enzymatic and physical characteristics of cloudy apple juices. Agricultural and Food Science 25: 34-43. DOI: 10.23986/afsci.52811. 